\title{
Performance of Nine Onion Cultivars in Southern Puerto Rico'
}

\author{
Gerardo Mangual Crespo and Francisco H. Ortiz ${ }^{2}$
}

\section{ABSTRACT}

\begin{abstract}
Nine onion cultivars were evaluated for yield and total solids content. Hybrid onion Granex 33 was the highest yielder with $36,476 \mathrm{~kg} / \mathrm{ha}$ and $7.6 \%$ total solids, while Red Creole was the lowest yielder with only $16,302 \mathrm{~kg} / \mathrm{ha}$, and an excellent total solids content of $14 \%$. Texas Grano 502 , our highest yielder in previous experiments, ranked second with $33,895 \mathrm{~kg} / \mathrm{ha}$ and an acceptable total solids percentage of 7.8.
\end{abstract}

\section{INTRODUCTION}

Onions, for dry bulb production, planted during the cool, dry and shortday period of the year have yielded very well in southern Puerto Rico (1, $5)$.

Alers et al. (1) reported yields ranging from 19.5 to 22 metric tons/ha for variety Texas Grano 502, and mentioned the possibility of obtaining yields of over 36.5 metric tons/ha in lowland areas. Mangual-Crespo (5) also reported yields of over 20 metric tons/ha for Texas Grano 502 planted during November at the same site.

According to Jones and Mann (3), onions are cultivated either for fresh consumption-generally big bulbs, slightly pungent, but in general, of low total solids content, bulbs not suitable for prolonged storage; or for industrial purposes, mainly powder-generally compact bulbs, high total solids content, narrow necks and pungent-conditions which make them better suited for long storage.

The planting of onion varieties with high total solids could probably extend the storage period of our onions for fresh consumption.

The main objective of this work was to determine the yield and total solids content of nine commercial onion cultivars and their adaptability to the conditions prevailing in southern Puerto Rico.

\section{MATERIALS AND METHODS}

An onion seedbed, metal flats $(60 \times 38 \times 8 \mathrm{~cm})$, was sown at the Fortuna Experiment Substation in November 1978. The soil is a San Antón silt loam (Cumulic Haplustolls, fine-loamy, mixed, non acid, iso-

\footnotetext{
${ }^{1}$ Manuscript submitted to Editorial Board September 10, 1979.

${ }^{2}$ Assistant Agronomists, Agricultural Experiment Station, Mayagüez Campus, University of Puerto Rico, Rio Piedras, P.R. The authors acknowledge the assistance of Dr. M. A. Lugo López, and of Mr. Edelmiro J. Rodríguez, Food Technology Laboratory, who aided in determining total solids.
} 
hyperthermic (4). It had a $\mathrm{pH}$ of 6.5 , a $\mathrm{CEC}\left(\mathrm{NH}_{4} \mathrm{OAc}\right)$ of 29.0 meq in the topsoil which decreased to 22.5 meq in the subsoil.

Nine commercial cultivars-Red Creole, Excel, Excel G, Eclipse, Granex 429, Hybrid Onion Granex 33, New Mexico Yellow Grano, Texas Grano 502 PRR and Texas Grano 502-were used with the latter as the check. The sets were planted in the field December 29, 1978.

Dacthal $\mathrm{W}-75^{3}$ was used as a preemergent herbicide immediately after transplanting at the rate of $11.25 \mathrm{~kg} / \mathrm{ha}$ of the active ingredient.

Fertilizer, $112 \mathrm{~kg} / \mathrm{ha}$ each of $\mathrm{N}, \mathrm{P}_{2} \mathrm{O}_{5}$ and $\mathrm{K}_{2} \mathrm{O}$, was banded and left uncovered immediately after transplanting.

During the experimental cycle, $57 \mathrm{~mm}$ rainfall was supplemented by $135 \mathrm{~mm}$ irrigation. Table 1 shows the climatological conditions. The experimental plots consisted of 4 beds $4.5 \mathrm{~m}$ long and $1 \mathrm{~m}$ apart; there were two rows of plants per bed. A complete block design with four replications was used.

TABLE 1.-Climatological data covering the experimental cycle from December to April, 1978-79

\begin{tabular}{lcccc}
\hline \multirow{2}{*}{ Month } & Rainfall & \multicolumn{2}{c}{ Temperature } & $\begin{array}{c}\text { Supplementary irri- } \\
\text { gations }\end{array}$ \\
\cline { 3 - 4 } & & Max & Min & No \\
December (27-31) & 0 & ${ }^{\circ} \mathrm{C}$ & ${ }^{\circ} \mathrm{C}$ & 1 \\
January & 16.5 & 30 & 19 & 7 \\
February & 11.0 & 29 & 18 & 3 \\
March & 29.0 & 31 & 19 & 0 \\
\hline \multicolumn{1}{c}{ Total } & 56.5 & & 19 & 11 \\
\hline
\end{tabular}

Harvesting of the four inner rows of each plot began March 29, 1979. A sample of ten bulbs was collected from each plot for diameter measurements. Fresh weights were taken at that time. The bulbs were stored in a well ventilated room for 10 days for curing purposes, after which they were again weighed, and an additional composite sample per variety was taken for total solids determination.

Total solids analyses were performed with the vacuum-oven method (2).

\section{RESULTS AND DISCUSSIONS}

Table 2 shows the marketable yield and total solids percentage of the nine cultivars under trial.

\footnotetext{
${ }^{3}$ Trade names in this publication are used only to provide specific information. Mention of a trade name does not constitute a warranty of equipment or materials by the Agricultural Experiment Station of the University of Puerto Rico, nor is this mention a statement of preference over other equipment or materials.
} 
Hybrid Onion Granex 33 was the highest yielder with $36,476 \mathrm{~kg} / \mathrm{ha}$, significantly superior to varieties Excel G and Red Creole, but not to the others. Texas Grano 502, our best yielder in previous experiments, ranked second with $33,895 \mathrm{~kg} / \mathrm{ha}$.

All yields obtained, except that of Red Creole, were above the average commercial production of 8.1 metric tons/ha in the United States; and cultivars Eclipse, Hybrid Granex 33, Granex 429 and Excel yielded four times as much as the average. Red Creole was the lowest yielder with only $16,302 \mathrm{~kg} / \mathrm{ha}$ but had the highest total solids percentage (14.01). Texas Grano 502 had a total solids percentage of 7.8; the other cultivars ranged from 7.1 to 8.3 .

The relatively high total solids content in this experiment could be agronomically explained in terms of the differences in soil, fertilizers,

TABLE 2.-Mean marketable yield and total solids of nine onion cultivars planted at the Fortuna Experiment Substation, 1978

\begin{tabular}{lcc}
\hline \multicolumn{1}{c}{ Cultivar } & Marketable yield ${ }^{1}$ & Total solids $^{\circ}$ \\
\hline Hybrid Onion Granex 33 & K $/ \mathrm{ha}$ & $\%$ \\
Texas Grano 502 & $36,476^{2} \mathrm{a}$ & 7.62 \\
Excel & $33,895 \mathrm{a}$ & 7.84 \\
Granex 429 & $33,623 \mathrm{a}$ & 8.27 \\
Eclipse & $31,314 \mathrm{ab}$ & 7.98 \\
New Mexico Yellow Grano & $28,800 \mathrm{ab}$ & 7.10 \\
Texas Grano 502 PRR & $26,355 \mathrm{ab}$ & 8.18 \\
Excel G & $21,940 \mathrm{ab}$ & 7.74 \\
Red Creole & $18,001 \mathrm{~b}$ & 8.18 \\
\hline
\end{tabular}

\footnotetext{
${ }^{1}$ Means of four replicates.

${ }^{2}$ Means in column followed by one or more letters in common do not differ significantly at the $5 \%$ probability level.
}

irrigation and general climatological conditions as compared to those encountered by Mendt et al. (6).

Varieties Excel, Excel G, and Eclipse showed some susceptibility to bacterial blight. Kocide 101 was used unsuccessfully.

\section{RESUMEN}

Se evaluaron nueve cultivares de cebolla en la costa sur de Puerto Rico con el propósito de determinar sus rendimientos y el porcentaje de sólidos totales.

El híbrido Granex 33 produjo el rendimiento más elevado con 36,476 $\mathrm{kg} / \mathrm{ha}$ y $7.6 \%$ de sólidos totales, mientras que Red Creole produjo $16,302 \mathrm{~kg} / \mathrm{ha}$, con el porcentaje de sólidos totales más alto, $14.01 \%$.

Las variedades Excel, Excel G y Eclipse demostraron susceptibilidad al tizón bacteriano. 


\section{LITERATURE CITED}

1. Alers, S., Orengo, E., and Cruz-Pérez, L., 1979. The influence of various N-P-K fertilizer levels on onion production in southern Puerto Rico, J. Agri. Univ. P.R. 63 (2): 111-15.

2. Association of Official Agricultural Chemists, 1970. Official Methods of Analyses, 11th ed, Washington, D.C.

3. Jones, H. and Mann, L., 1963. Onions and their Allies. London, Leopard Hill (Books) limited. New York, Interscience Publishers, Inc.

4. Lugo-López, M. A. and Rivera, L. H., 1976. Taxonomic classification of the soils of Puerto Rico, Agri. Exp. Stn. Univ. P. R., Bull 245.

5. Mangual-Crespo, G., Orengo, E., and Ramirez, C. T. Effect of plant spacing and fertilizer levels on yield and dry bulb weight of onions cv. Texas Grano 502. Unpublished data.

6. Mendt, R., Medrano, C. y Figuera, A., 1976. Evaluación de cultivares de cebolla para consumo fresco y de uso industrial, 24th Annual Cong. Trop. Region, P. R., Dec. 510. 